Article

\title{
Quality Assurance of International Fruit Supply Chains via Techno-Management
}

\author{
Tippawong Rodjanatham ${ }^{1, *}$ and Tenzin Rabgyal ${ }^{2}$ \\ 1 Chief of Planning and Evaluation Section, Army Training Command Language Center, Royal Thai Army, \\ Bangkok 10300, Thailand and Former Scholar at Department of Agrotechnology \& Food Sciences, \\ Wageningen University, 6708 PB Wageningen, The Netherlands \\ 2 Agribusiness Management, School of Environment, Resources and Development, Asian Institute of \\ Technology, Pathum Thani 12120, Thailand; tenzin@ait.ac.th \\ * Correspondence: amm.ozone@gmail.com; Tel.: +66-81-953-3696
}

Received: 16 February 2020; Accepted: 31 March 2020; Published: 3 April 2020

\begin{abstract}
Fruit plays an important role in tropical horticulture and has high commercial value in domestic and international markets. There are several factors affecting the quality of fruit in the supply chain, including type of fruit, storage, distribution, harvesting, and packaging. This research was conducted to analyze the current situation regarding quality assurance in the international supply chain of tropical fruits by developing a tool to assess the level of quality assurance and chain collaboration. A techno-managerial approach was used in this research; therefore, a three-axes model was developed as the techno-managerial model. The three axes consist of degree of quality assurance, classes of fruit (regarding risk of chemical residue and quality deterioration), and degree of chain collaboration. For this study, five situations were chosen at random by considering the different degrees (from lowest degree to highest degree) of quality assurance and chain collaboration for each class of fruit. The results show that $10 \%-60 \%$ of importers require their suppliers to comply with quality assurance standards in Situation 1 (low-risk fruits, low degree of quality assurance, and low degree of chain collaboration) and Situation 2 (medium-risk fruits, low degree of quality assurance, and low degree of chain collaboration). Almost $100 \%$ of imported fruits have permeable peels which are removed before consumption. This group of fruit has medium-high perishable rate. With different types of fruits, the importers set different requirements with respect to quality assurance. Regarding chain participation, the most common situation is Situation 1 (more than $60 \%$ ), in which the retailer has the biggest influence. The most common situation for suppliers who supply the product to import companies falls into Situation 2. This means that most of the commodities have permeable peels, so the suppliers follow the basic quality assurance standards and are at the low level in chain co-operation. Lastly, considering the usefulness of the model, it can be employed as a good tool in assessing the situation in practice.
\end{abstract}

Keywords: fruit; techno-managerial; risk; quality assurance; chain collaboration; permeable peels; perishable

\section{International Tropical Fruit Supply Chain Situation in the Present Day}

The global population is expected to reach nine billion by the year 2050, requiring up to $70 \%$ more food than at present and demanding food production systems and food chains to become sustainable [1].

The management of food quality is complex since it must deal with the complexity of food characteristics and human behavior. Scientific knowledge is needed to study food characteristics. 
Additionally, human behavior also has influence on food quality [2]. Managerial knowledge should be used to analyze problems of quality generated by humans as well.

In consideration of the preceding factors, there is an urgent need for sustainability and improvement in the efficiency and effectiveness of food chains, with the related challenges of increasing complexity in food supply chains, environmental limitations, the increase in the aging population, and the changing patterns of consumer choice and food consumption. Within this context, food safety remains one of the main concerns of global food security [3].

As is widely known, the benefits of consumption of fruit and vegetables to human health are linked with prevention of an array of diseases such as coronavirus, degenerative disorders, cancer, and cardiovascular problems [4]. Therefore, the consumption of fruit is promoted among consumers by nutritionists, researchers, and government and international organizations [5].

Because of the important role that fruit plays in horticulture and commercial markets [6], it is necessary to consider the various factors that affect the quality of fruit in the supply chain. Consequently, quality assurance is essential in minimizing problems in tropical fruit trading [7]. Globally, growing regions of fruits can be classified into three groups as follows: the temperate zone, subtropical zone, and tropical zone [6].

Analysis of the present-day situation of the international supply chain of tropical fruit required the development of a useful method to determine quality assurance and chain collaboration. In this research, only tropical fruits, such as papaya, mango, banana, pineapple, durian, guava, longan, lychee, mangosteen, passion fruit, and rambutan were considered.

Tropical fruit is imported from developing countries into developed countries. However, different client groups may require different product attributes. A techno-managerial approach was used and applied to analyze and explain the problems of safety and constant quality in this research.

The objective of this research is to develop a techno-managerial model as a tool to assess the level of quality assurance and chain collaboration.

The research is organized into four stages: stage one provides theoretical review of the characteristics of tropical fruit and the process characteristics, quality assurance system, and the chain collaboration in international fruit supply chains; the second stage is the research model development based on the theoretical review; evaluation of the research model is considered in the third stage; and the paper concludes by summarizing the main results and discussing implications for the future research.

\section{Techno-Managerial Perspectives in International Tropical Fruit Supply Chains}

Quality assurance standards have both managerial and technological aspects. The chain collaboration in international fruit supply chains is considered as the managerial approach because both aspects assess the safety and constant quality of the produce. Technology management can be defined as the integrated planning, design, optimization, operation, and control of technological products, processes, and services. A concise definition would be the management of the use of technology for human benefit.

The techno-managerial approach was introduced as a method to solve the quality problem. To ensure that tropical fruit is safe and the quality is constant, the characteristics of tropical fruit and the process characteristics are considered as technological approaches in determining safety and constant quality [8].

\subsection{Technological Approach}

The characteristics of fruit have influence on residue potential which can occur in edible part of fruits. The residue potential of fruits depends on type of fruit peel [9].

Fruit can be divided into two groups depending on their speed of ripening after harvest. Non-climacteric ripening fruit produce very small amount of ethylene and do not respond to ethylene treatment. There is no characteristic increased rate of respiration or production of carbon dioxide. 
Moreover, non-climacteric ripening fruit ripen only before harvest [10]. Their sugars and acid content do not increase after harvest. Maturation and ripening are gradual processes. For instance, this group includes tropical fruits such as lychee, pineapple, and watermelon. Climacteric fruits enter "climacteric phase" after harvest. They continue to ripen; during the ripening process, the fruits emit ethylene along with increased rate of respiration. In addition, climacteric fruits, including papaya, mango, banana, guava, and passion fruit, can continue their ripening process after being removed from the plants [11].

To prevent the risk of hazards and to maintain constant quality before reaching consumers, it is crucial to know the factors of product/process characteristics that promote risk hazards or affect quality. The factors significantly affecting quality during cultivation include choosing of suitable fruit varieties by plant breeding, cultural practices such as sowing date, and environmental effects such as temperature. Unacceptable pesticide residue in seeds and the application of pesticide during cultivation should be considered as safety concerns. Foodborne pathogens, such as Bacillus cereus and Salmonella, bacteria, and fungi that cause postharvest disease, may come with seeds. In addition, microbial contamination of fruits has been reported to arise [12].

Concerning harvest conditions, factors influencing quality are time of harvest and mechanical injury to fruit, because many biochemical changes take place during the growth and ripening of fruit, e.g., enzymatic-catalyzed browning caused by mechanical injury leads to undesired brown coloration and softening during ripening [13]. Therefore, farmers must harvest during the proper period and employ appropriate techniques of equipment usage.

The determination of physical properties of manufactured foods are the compositional characteristics of raw materials, their actual composition (e.g., addition of preservatives), and the conditions of their processing (e.g., temperature and pressure).

The respiration rate after harvest characterizes types of fruits. Most fleshy fruits have an increasing respiratory rate followed by ripening (i.e., color, flavor, and texture changes), which have a large influence on their quality. During storage and distribution, the relevant factors affecting fresh produce quality are:

- Initial bacterial load (Presence of a high initial bacterial load can increase spoilage, which causes shorter shelf life.)

- Temperature (Low temperature reduces the respiration rate due to lower oxygen diffusion gradient.)

- Humidity (High relative humidity (RH) is favorable for growth of molds because of high water activity for mold to grow.)

- Atmosphere (Controlled atmosphere is an agricultural storage method in which the concentrations of oxygen, carbon dioxide, and nitrogen are regulated, which can slow down respiration and decay.) [13].

Packaging material should have good barrier properties to prevent further chemical and bacterial contamination and/or diffusion of moisture and oxygen. Modified gas conditions, e.g., low oxygen, maintain the quality of fresh produce.

\subsection{Techno-Managerial Approach}

Quality assurance (QA) systems used in the food industry aim at prevention of problems, while also assuring that the same problems will not occur in the future [14]. Additionally, consumers in developed countries are demanding transparency in the supply chain [15]. Existing Quality Assurance Standards were evaluated regarding safety, constant quality, and transparency in the supply chain of fruit.

In the fresh produce industry, attention to QA has increased considerably due to a greater concern by consumers with food safety and high demand for consistent good quality. Complying with specific systems is also important due to the legislative requirements of the European market. QA is of major importance to the agribusiness and industry for the following reasons [16]: 
- Agricultural products are often perishable and likely to decay rapidly due to physiological processes and/or microbiological contamination.

- Most agricultural products are harvested seasonally.

- Products are often variable owing to different cultivation and seasonal variables, which may be difficult to monitor.

- Numerous farms operate production on a small scale.

This complex situation requires implementation of QA systems to ensure the production of safe, high-quality food. Moreover, safety and quality assurance should be integrated by incorporating activities starting from farm to fork. By bringing a quality assurance system to the chain, problems can be prevented. Moreover, if safety or quality decreases, it is possible to go back and find a solution for the problems of that type of produce [17].

The aim of quality assurance is to guarantee that quality requirements, such as product safety, reliability, service, etc., are realized by use of the quality assurance system. A quality assurance system is described in ISO 8402 as the organizational structure, responsibilities, processes, procedures, and resources for implementing quality management. The common QA systems in the food industry are good practices (GP) (e.g., Good Manufacturing Practice (GMP) and Good Hygienic Practice (GHP)), Hazard Analysis Critical Control Points (HACCP), International Standard Organization (ISO), and combined systems such as British Retail Consortium (BRC) [18]. Eurep-GAP is a quality assurance system which is specific to vegetable and fruit production.

Problems impacting the agri-food business, such as mislabeling, and allergies increase the demand for transparency in the food chain to build more confidence among consumers. It is stated that transparency in food chains means "open access to information on a food product's safety and quality status". Transparency provides verification of the origin/traceability, composition, safety and claims, and the possibility to go back to the point in the chain where the problem started. The information must be recorded at the point of the chain to facilitate traceability [19].

Transparency in the chain can be achieved by:

- Food safety-based standards

- Accredited, recognized standards

- Defined auditor criteria

- Third-party certification

In order to evaluate the degree of transparency of each QA system, the status of transparency of QA systems has been compared. GMP/GAP has the lowest degree of difficulty to implement and has the lowest degree of transparency. HACCP and SQF 2000/BRC have a medium degree of difficulty to implement and of transparency, respectively.

The common QA systems are compared with respect to the assurance of safety and quality. The elements of Good Manufacturing Practice (GMP) linked with hygiene (commonly referred to as Good Hygienic Practice (GHP) requirements) shape the foundation for the operation of a hygienic food operation. GMP/GHP is essential in assisting the application of HACCP. Assuring the production of safe food can be accomplished by applying HACCP. HACCP deals with preventing contamination hazards by monitoring the critical points in the food product and process. HACCP emphasizes good safety specifically. HACCP can fit in well with a management system (ISO) and can be incorporated into it. In addition to food safety, other quality attributes including constant quality are results of implementing ISO. TQM gives added confidence that products comply with quality requirements. However, in this project, TQM is not considered.

The QA systems are evaluated with respect to food safety specific to fresh produce and market impact. However, the Safe Quality Food (SQF) system is not used for evaluation here because it is mainly a standard of Europe. 


\subsection{Managerial Approach}

Food supply chains are composed of many actors at different parts of the chain. One typical characteristic of the traditional supply chain is that the actors in the chain perceive product quality through different concepts [20]. This can lead to quality problems in the supply chain. The quality perceptions of each actor is shown in Table 1.

Table 1. Actors in the chain and quality perception.

\begin{tabular}{cccccc}
\hline \multicolumn{5}{c}{ Actors in the Chain and Quality Perception } \\
\hline Breeder & Grower & Auction & $\begin{array}{c}\text { Distribution } \\
\text { and Storage }\end{array}$ & Retailer & Consumer \\
\hline $\begin{array}{c}\text { Vitality seeds, } \\
\text { yield }\end{array}$ & $\begin{array}{c}\text { Productivity, } \\
\text { uniformity, } \\
\text { disease } \\
\text { resistance }\end{array}$ & $\begin{array}{c}\text { Uniformity, } \\
\text { reliable supply, } \\
\text { constant } \\
\text { quality }\end{array}$ & $\begin{array}{c}\text { Keepability, } \\
\text { availability, } \\
\text { damage } \\
\text { sensitivity }\end{array}$ & $\begin{array}{c}\text { Good shelf-life, } \\
\text { diversity, } \\
\text { appearance, } \\
\text { low waste }\end{array}$ & $\begin{array}{c}\text { Taste, health, } \\
\text { sustainable, } \\
\text { convenience, } \\
\text { constant quality }\end{array}$ \\
\hline
\end{tabular}

\section{Chain Participation}

The production of safe food requires participation along the food chain. The primary responsibility lies with those who produce, process, and trade in food. It covers the whole food chain from primary production to final consumption. Responsible persons include farmers, fishermen, slaughterhouse operators, food processors, transport operators, and distributors (wholesale and retail). Relevant information regarding the safety of food should be provided to the next person in the food chain. Every firm is part of a value system, and chain improvement can be done by means of cooperation [21]. The building of value-added partnerships (VAP) is very important for firms in the management of agribusiness in order to meet the customer needs for safety.

Communication along the postharvest chain must be carried out effectively, e.g., in the fresh produce chain, at the cultivation step, growers cultivate fruit by complying with good agricultural practices. In the handling, packing, and storage steps, the manufacturers must accomplish those steps hygienically. By doing so, the chain can achieve production of better and safer products.

In this research, the grower, processor, exporter, importer, wholesaler, retailer, and consumer are participators of this chain. For the purposes of further research, the degree of collaboration between involved actors will be analyzed by calculating the total number of actors who are collaborating in the fruit chain. The optimal degree of collaboration in terms of promoting food safety will be calculated out afterwards.

\section{Materials and Methods}

\subsection{Development of the Research Model}

Based on the theoretical review in the previous section, a research model was developed. It is presented in Figure 1. A total of 27 situations were used as a tool to determine the current situation in the international fruit supply chain. The situations were categorized as low, medium, or high, with regards to risk, quality assurance, and collaboration in the international fruit supply chain. Thus, each type of fruit requires different optimal degrees of quality assurance and chain participation to be certain of safety and constant quality, depending on their characteristics. Therefore, the research model comprised three axes.

Axis 1 contained three degrees of quality assurance (low, medium, and high), and this axis takes the techno-managerial approach. Axis 2 contained three classes of fruit (Class 1, Class 2, and Class 3), and this axis takes the technological approach. Axis 3 included three degrees of chain collaboration, and this axis takes the managerial approach. From this model, 27 diverse situations in the international fruit supply chain were derived. The 27 situations were used as a tool to determine the current situation in the chain in practice. The details of each axis are explained in the next section. 


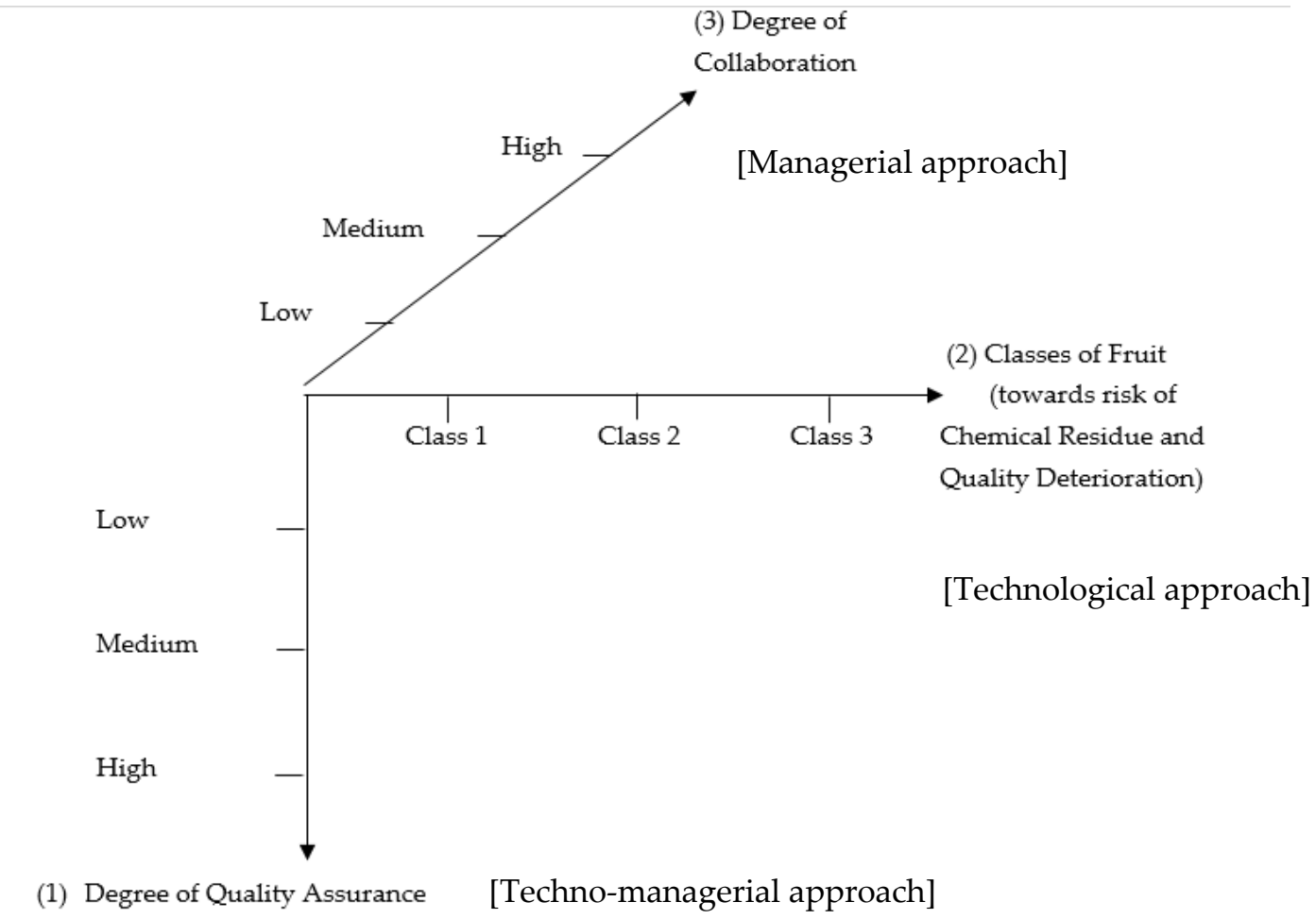

Figure 1. Three axes model as a research model.

\subsection{Explanation of Three Axes}

\subsubsection{Axis 1: The Degree of Quality Assurance}

Axis 1, the degree of quality assurance type was summarized in three levels according to their qualifications. Derivation from Figure 1 is presented in Table 2. In terms of quality assurance system, MRLS, GAP or GMP, or HACCP, BRC and/or EUREP-GAP, and ISO had a higher-level degree of quality assurance, whereas MRLS, GAP or GMP, and Codex had a lower level of degree of quality assurance standard.

Table 2. Axis 1: degree of quality assurance in three levels.

\begin{tabular}{cccc}
\hline \multirow{2}{*}{ Qualifications } & \multicolumn{3}{c}{ Degree of Quality Assurance } \\
\cline { 2 - 4 } & Low Level & Medium Level & High Level \\
\hline Legislation & Yes & Yes & Yes \\
Food Safety-Based Standard & Yes & Yes & Yes \\
$\begin{array}{c}\text { Constant Quality Standard } \\
\text { Transparency in its Safety }\end{array}$ & Low & Low & High \\
Third-Party Certification & Medium & High & Yes \\
(regarding food safety and & & & Yes \\
constant quality) & No & & MRLS, GAP or GMP, \\
Standards that will be applied to & MRLS, GAP or GMP, and & MRLS, GAP or GMP, & HACCP, BRC and/or \\
the chain & CODEX & HACCP, and CODEX & EUREP-GAP, and ISO \\
\hline
\end{tabular}

Yes: It is compulsory to be in compliance with that factor. No: It is not required to be in compliance with that factor. Low: It is required to be in compliance with that factor to a low degree. Medium: It is required to be in compliance with that factor to a medium degree. High: It is required to be in compliance with that factor to a high degree.

\subsubsection{Axis 2: The Degree of Exposure to Safety and Constant Quality}

Axis 2, the degree of exposure to safety and constant quality of tropical fruit was summarized into three classes. Derivation from Figure 1 is presented in Table 3. In terms of classes of the type of 
fruit with respect to safety and constant quality, Class 3 fruits had a higher level degree of residue potential and sensitivity towards the deterioration process, whereas Class 1 fruits had a lower level degree of residue potential and sensitivity towards the deterioration process.

Table 3. Axis 2: degree of exposure to safety and constant quality of tropical fruits in three classes.

\begin{tabular}{cccc}
\hline \multirow{2}{*}{ Factors } & \multicolumn{2}{c}{ Classes of the Fruits with Respect to Safety and Constant Quality } \\
\cline { 2 - 4 } & Class 1 & Class 2 & Class 3 \\
\hline $\begin{array}{c}\text { Product characteristics } \\
\text { towards safety }\end{array}$ & $\begin{array}{c}\text { Fruits enclosed with thick } \\
\text { peels which are removed } \\
\text { before consumption }\end{array}$ & $\begin{array}{c}\text { Fruits enclosed with peels } \\
\text { which are permeable } \\
\text { (Chemical residue can } \\
\text { penetrate the skin.) }\end{array}$ & $\begin{array}{c}\text { Fruits which are } \\
\text { normally consumed } \\
\text { with skin }\end{array}$ \\
\hline $\begin{array}{c}\text { Degree of perishability } \\
\text { towards constant quality }\end{array}$ & $\begin{array}{c}\text { Slow perishable rate or long } \\
\text { shelf life }\end{array}$ & $\begin{array}{c}\text { Moderately fast perishable } \\
\text { rate or medium-short } \\
\text { shelf life }\end{array}$ & $\begin{array}{c}\text { Moderately fast } \\
\text { perishable rate or } \\
\text { medium-short shelf life }\end{array}$ \\
\hline $\begin{array}{c}\text { Examples of } \\
\text { commodities }\end{array}$ & Durian & $\begin{array}{c}\text { Pineapple, mango, banana, } \\
\text { papaya, and passion fruit }\end{array}$ & Guava \\
\hline
\end{tabular}

\subsubsection{Axis 3: The Degree of Collaboration Complexity of the Chains}

Axis 3, the degree of collaboration complexity of the chains was summarized into three classes. Derivation from Figure 1 is presented in Figure 2. In terms of degree of collaboration complexity of the chain at a high level of collaboration, the retailer had the biggest influence on product quality assurance. In addition, the processor, the exporter, the importer, and the wholesaler communicated with the grower to raise the level of quality assurance. At a medium level of collaboration, in addition to the retailer, there were also the grower, the processor, the exporter, and the importer who participated to improve the level of quality assurance. At a low level of collaboration, the retailer played the most important role. The grower, the processor, and the exporter in developing countries put forth strong efforts to assure safe and constant quality produce.

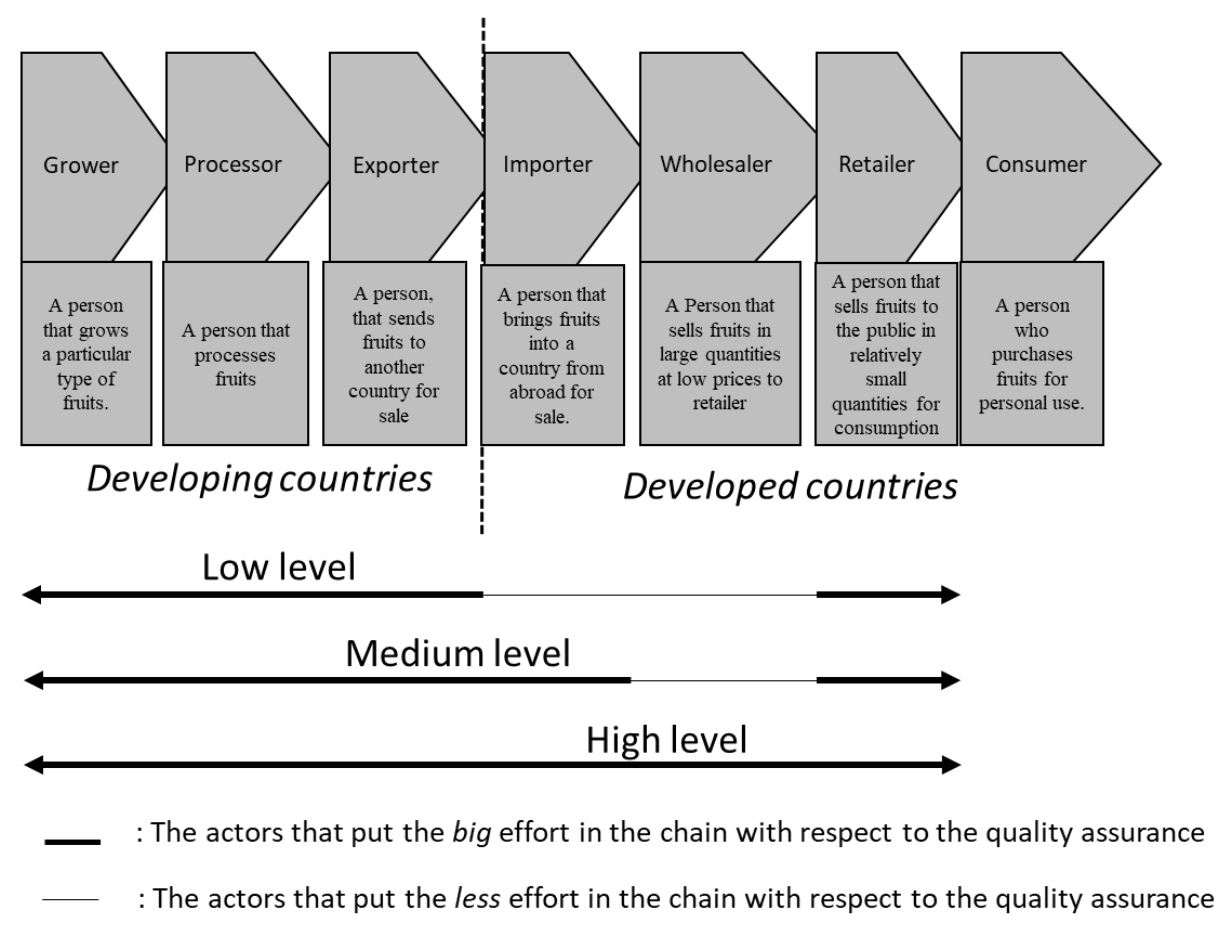

Figure 2. Degree of collaboration complexity of the chain. 


\subsection{Model Assessment}

From Tables 2 and 3 and Figure 2 (the combination of the three axes in the research model), 27 possibilities, which differ in degree of quality assurance, classes of fruits, and chain collaboration, are derived as depicted in Table 4. Concerning the three classes of each axis above, the table below shows the combination of the different degrees of quality assurance, chain collaboration, and classes of fruits, which are derived from the three-axes model.

Table 4. Combination of 27 situations in the international fruit supply chain.

\begin{tabular}{|c|c|c|c|c|c|c|c|c|c|}
\hline \multirow{3}{*}{$\begin{array}{l}\text { Classes of Tropical } \\
\text { Fruits towards Safety } \\
\text { and Constant Quality }\end{array}$} & \multicolumn{9}{|c|}{ Degree of Quality Assurance } \\
\hline & \multicolumn{3}{|c|}{$\begin{array}{c}\text { Low } \\
\text { Degree of Collaboration }\end{array}$} & \multicolumn{3}{|c|}{$\begin{array}{c}\text { Medium } \\
\text { Degree of Collaboration }\end{array}$} & \multicolumn{3}{|c|}{$\begin{array}{c}\text { High } \\
\text { Degree of Collaboration }\end{array}$} \\
\hline & Low & Medium & High & Low & Medium & High & Low & Medium & High \\
\hline Class 1 & 1 & 2 & 3 & 4 & 5 & 6 & 7 & 8 & 9 \\
\hline Class 2 & 10 & 11 & 12 & 13 & 14 & 15 & 16 & 17 & 18 \\
\hline Class 3 & 19 & 20 & 21 & 22 & 23 & 24 & 25 & 26 & 27 \\
\hline
\end{tabular}

Table 4 indicated that there were 27 possible situations in practice, but many were used to develop the tool. According to Table 5, five situations were chosen at random by choosing from the different degrees (from low degree to high degree) of quality assurance and chain collaboration from each class of fruit to make a grid which is a tool to assess the performance in the fruit chains.

Table 5. Representatives of situations in the fruit chains as a tool to assess situations in practice.

\begin{tabular}{|c|c|c|c|c|c|}
\hline \multirow{2}{*}{ Factor } & \multicolumn{5}{|c|}{ Situation } \\
\hline & Situation 1 & Situation 2 & Situation 3 & Situation 4 & Situation 5 \\
\hline Class of fruits & $\begin{array}{l}\text { Fruits that have } \\
\text { thick peels and low } \\
\text { perish-ability rate, } \\
\text { such as pineapple }\end{array}$ & $\begin{array}{l}\text { Fruits that have } \\
\text { permeable } \\
\text { peels which are } \\
\text { removed before } \\
\text { consumption, } \\
\text { such as mango } \\
\text { and banana }\end{array}$ & $\begin{array}{l}\text { Fruits that have } \\
\text { permeable } \\
\text { peels which are } \\
\text { removed before } \\
\text { consumption, } \\
\text { such as mango } \\
\text { and banana }\end{array}$ & $\begin{array}{l}\text { Fruits that have } \\
\text { peels which are } \\
\text { consumed, } \\
\text { such as guava }\end{array}$ & $\begin{array}{l}\text { Fruits that have } \\
\text { peels which are } \\
\text { consumed, such } \\
\text { as guava }\end{array}$ \\
\hline $\begin{array}{c}\text { Degree of } \\
\text { quality } \\
\text { assurance }\end{array}$ & $\begin{array}{l}\text { MRLs, GAP or } \\
\text { GMP, and Codex }\end{array}$ & $\begin{array}{c}\text { MRLs, GAP or } \\
\text { GMP, and } \\
\text { Codex }\end{array}$ & $\begin{array}{l}\text { MRLs, GAP or } \\
\text { GMP, and } \\
\text { HACCP and } \\
\text { Codex }\end{array}$ & $\begin{array}{l}\text { MRLs, GAP or } \\
\text { GMP, and } \\
\text { HACCP and } \\
\text { Codex }\end{array}$ & $\begin{array}{l}\text { MRLs, GAP or } \\
\text { GMP or Hygiene } \\
\text { Code, HACCP, } \\
\text { EUREP-GAP } \\
\text { and/or BRC, } \\
\text { and ISO }\end{array}$ \\
\hline $\begin{array}{l}\text { Degree of chain } \\
\text { collaboration }\end{array}$ & $\begin{array}{l}\text { There is } \\
\text { participation } \\
\text { between retailer, } \\
\text { grower, processor, } \\
\text { and exporter }\end{array}$ & $\begin{array}{l}\text { There is } \\
\text { participation } \\
\text { between } \\
\text { retailer, grower, } \\
\text { processor, and } \\
\text { exporter }\end{array}$ & $\begin{array}{l}\text { There is } \\
\text { participation } \\
\text { between } \\
\text { retailer, grower, } \\
\text { processor, } \\
\text { exporter, and } \\
\text { importer }\end{array}$ & $\begin{array}{l}\text { There is } \\
\text { participation } \\
\text { between } \\
\text { retailer, grower, } \\
\text { processor, } \\
\text { exporter, and } \\
\text { importer }\end{array}$ & $\begin{array}{l}\text { There is } \\
\text { participation } \\
\text { between retailer, } \\
\text { grower, processor, } \\
\text { exporter, importer, } \\
\text { and wholesaler }\end{array}$ \\
\hline
\end{tabular}

The explanation of these five situations is as follows:

(1) Situation 1: The suppliers of fruits having thick peels and low perishability rate, or low-risk fruits such as pineapple, follow MRLS, GAP or GMP, and Codex. In the chain, there is participation between retailer, grower, processor, and exporter to achieve the quality assurance of safety and constant quality. Therefore, Situation 1 is composed of low-risk fruits, low degree of quality assurance, and low degree of chain collaboration.

(2) Situation 2: The suppliers of fruits having permeable peels which are removed before consumption, such as mango and banana, follow MRLS, GAP or GMP, and Codex. In the chain, there 
is participation between retailer, grower, processor, and exporter to achieve the assurance of safety and constant quality. Therefore, Situation 2 is composed of medium-risk fruits, low degree of quality assurance, and low degree of chain collaboration.

(3) Situation 3: The suppliers of fruits having permeable peels which are removed before consumption, such as mango and banana, follow MRLS, GAP or GMP, and HACCP and Codex. Retailer, grower, processor, exporter, and importer participate to achieve the assurance of safety and constant quality. Therefore, Situation 3 is composed of medium-risk fruits, medium degree of quality assurance, and medium degree of chain collaboration.

(4) Situation 4: The suppliers of fruits having peels which are consumed, such as guava, follow MRLS, GAP or GMP, and HACCP and Codex. Retailer, grower, processor, exporter, and importer participate to achieve the assurance of safety and constant quality. Therefore, Situation 4 is composed of high-risk fruits, medium degree of quality assurance, and high degree of chain collaboration.

(5) Situation 5: The suppliers of fruits having peels which are consumed, such as guava, follow MRLS, GAP or GMP or Hygiene Code, HACCP, EUREP-GAP and/or BRC, and ISO. Retailer, grower, processor, exporter, importer, and wholesaler participate to achieve the assurance of safety and constant quality. Therefore, Situation 5 is composed of high-risk fruits, high degree of quality assurance, and high degree of chain collaboration.

\subsection{Evaluation of Research Model}

\subsubsection{Questionnaire}

To make the research model more operational, two types of questionnaires were developed. One was for import companies and the other was for experts in the international fruit chain. Both types of questionnaires were developed based on the situations in Table 5. The objective of developing the questionnaire was to assess the current situation of assuring quality.

The questions in the questionnaire asked the importers about the current situation in the chain and grouped them in one of the five situations in Table 5 . The questionnaire for experts was aimed at the same objective, but the experts were questioned to provide an overview of the quality assurance situations and chain collaboration in practice.

Both types of questionnaires were composed of three parts. Part 1 showed the most common situation for quality assurance of products with respect to safety and constant quality, and here, transparency was also assessed. In Part 2, product characteristics with respect to safety and constant quality were evaluated. In Part 3, the situation of chain participation was assessed.

\subsubsection{Qualitative Approach}

This study applied the qualitative approach by interviewing the managers or owners of import companies and the experts. Ten company managers and ten experts from the Agrotechnological Research Institute (ATO) were approached to have in-depth interview but only five from each side responded to participate in this research. The result obtained from managers and experts were an overview of the quality assurance situations, and chain collaboration in practice was taken into account. Therefore, the qualitative data from the interview was analyzed.

Note: The result from the in-depth interview was considered as the evaluation of the research model rather than summarizing the result. The research model was evaluated if it is suitable to assess the situation.

\section{Results}

Concerning the intensive interviewing of the managers or owners of import companies and the experts in the international supply chain to find the most common situation for tropical fruit importers in developed countries, the results are concluded separately for each part in the questionnaire. 


\subsection{The Result of Part 1}

There are $10 \%-60 \%$ of the importers who require their suppliers to comply with the quality assurance standards in Situations 1 and 2. Less than $10 \%$ of the importers require their suppliers to comply with the quality assurance standards in Situation 3 . When considered separately between the safety aspect, the constant quality aspect, and the transparency aspect, the answers were as follows:

First, concerning safety, the importers require basic quality assurance standards such as the hygiene code from their suppliers. They think that this is enough to guarantee the safety of the tropical fruit.

Second, regarding constant quality, the importers require the basic level of constant quality. The appearance must be good but small defects are acceptable. The external attributes and internal attributes are not considered in the requirements.

Lastly, concerning transparency, the importers also require the basic level of quality assurance standards to reach transparency. In summary, they require just the basic level of the quality assurance standards to be certain of safety, constant quality, and transparency.

\subsection{The Result of Part 2}

Almost $100 \%$ of imported fruits have permeable peels which are removed before consumption. This group of fruit has a medium-high perishable rate. In different types of fruits, the importers set different requirements with respect to quality assurance. The rankings from the most important attribute to the least important attribute are size, shape, color, aroma, texture, taste, and sugar content, respectively.

\subsection{The Result of Part 3}

Regarding chain participation, the most common situation is Situation 1 (more than $60 \%$ ). The retailer has the biggest influence. The three actors in developing countries (the grower, the processor, and the exporter) play the biggest role in ensuring the quality of the produce. In less than $10 \%$ of the situations, the importer (or the importer and wholesaler) are involved in assuring the quality.

\section{Discussion}

The most common situation for the suppliers who supply their product to import companies falls into Situation 2. This means that most of the commodities have permeable peels. The suppliers follow the basic quality assurance standard and are at the low level in chain cooperation. GMP and/or GAP and/or the hygiene code are the standards that they have implemented to assure safety. The presence of defects is used as a criterion to assure constant quality.

The retailer, the grower, the processor, and the importer are the actors who put effort into quality assurance. Therefore, in the future, they can improve their performance by complying with higher, more complex quality assurance standards and achieve greater cooperation in working with the other actors in the chain.

This study allowed us to know the overview of the quality assurance situations and chain collaboration in the international tropical fruit chains. Regarding to the model evaluation, the model gives a good overview in solving the quality problem by combining technological and managerial approaches.

\section{Conclusions and Implications for Future Research}

In conclusion, this research was conducted to analyze the current situation regarding quality assurance in the international supply chain of tropical fruits by developing a tool to assess the level of quality assurance and chain collaboration. The techno-managerial approach was used in this research; therefore, the three-axes model was developed as the techno-managerial model. The three axes are 
composed of degree of quality assurance, classes of fruits (with regard to the risk of chemical residue and quality deterioration), and degree of chain collaboration.

There were five situations selected at random, with the respondents choosing from among the different degrees (from low degree to high degree) of quality assurance and chain collaboration from each class of fruit. As a result, it was shown that $10 \%-60 \%$ of the importers require their suppliers to comply with the quality assurance standards in Situations 1 and 2. Almost $100 \%$ of imported fruits have permeable peels which are removed before consumption. This group of fruits has a medium-high perishable rate. In different types of fruits, the importers set different requirements with respect to quality assurance.

Regarding chain participation, the most common situation is Situation 1 (more than $60 \%$ ), in which the retailer has the biggest influence. The most common situation for suppliers who supply the product to import companies falls under Situation 2. This means that most of the commodities have permeable peels, and the suppliers follow the basic quality assurance standards and are at a low level in chain cooperation.

Considering the usefulness of the model, it can be employed as a good tool in assessing the situation in practice. Limitation of this research was mainly based on the theoretical review. It might not be suitable in application in practice directly. Future research can be carried out applying the quantitative approach.

Author Contributions: T.R. (Tippawong Rodjanatham) designed the research, collected data, interpreted results and wrote the paper. T.R. (Tenzin Rabgyal) collaborated in the literature review, checked results, reviewed and edited the contents of the research paper. Both authors analyzed the data and participated jointly in the discussion. All authors have read and agreed to the published version of the manuscript.

Funding: This research received no external funding.

Conflicts of Interest: The authors declare no conflict of interest.

\section{References}

1. King, T.; Cole, M.; Farber, J.M.; Eisenbrand, G.; Zabaras, D.; Fox, E.M.; Hill, J.P. Food safety for food security: Relationship between global megatrends and developments in food safety. Trends Food Sci. Technol. 2017, 68, 160-175. [CrossRef]

2. Abdullah, D.; Hamir, N.; Nor, N.M.; Krishnaswamy, J.; Rostum, A.M.M. Food quality, service quality, price fairness and restaurant re-patronage intention: The mediating role of customer satisfaction. Int. J. Acad. Res. Bus. Soc. Sci. 2018, 8, 211-226.

3. Beitzen-Heineke, E.F.; Balta-Ozkan, N.; Reefke, H. The prospects of zero-packaging grocery stores to improve the social and environmental impacts of the food supply chain. J. Clean. Prod. 2017, 140, 1528-1541. [CrossRef]

4. Calicioglu, O.; Flammini, A.; Bracco, S.; Bellù, L.; Sims, R. The Future Challenges of Food and Agriculture: An Integrated Analysis of Trends and Solutions. Sustainability 2019, 11, 222. [CrossRef]

5. Artés-Hernández, F.; Martinez-Hernández, G.B.; Aguayo, E.; Gómez, P.A.; Artés, F. Fresh-cut fruit and vegetables: Emerging eco-friendly techniques for sanitation and preserving safety. Postharvest Handl. 2017, 7-45. [CrossRef]

6. Iqbal, M.; Kachroo, J.; Sehar, H.; Kachroo, D. Income and employment increasing potentiality in various farming systems of various zones of Jammu regions. J. Pharmacogn. Phytochem. 2018, 7, 180-185.

7. Hussein, Z.; Fawole, O.A.; Opara, U.L. Harvest and Postharvest Factors Affecting Bruise Damage of Fresh Fruits. Hortic. Plant J. 2020, 6, 1-13. [CrossRef]

8. Milios, K.; Zoiopoulos, P.E.; Pantouvakis, A.; Mataragas, M.; Drosinos, E.H. Techno-managerial factors related to food safety management system in food businesses. Br. Food J. 2013, 115, 1381-1399. [CrossRef]

9. Salman, L.; Ahmed, I. Evaluation of Some Pesticide Residues in Fruits import by High Performance Liquid Chromatography. Al-Mustansiriyah J. Sci. 2017, 27. [CrossRef]

10. Sudheer, K.; Indira, V. Post Harvest Technology of Horticultural Crops; New India Publishing: New Delhi, India, 2007; Volume 7. 
11. Farcuh, M.; Rivero, R.M.; Sadka, A.; Blumwald, E. Ethylene regulation of sugar metabolism in climacteric and non-climacteric plums. Postharvest Biol. Technol. 2018, 139, 20-30. [CrossRef]

12. Park, S.; Szonyi, B.; Gautam, R.; Nightingale, K.; Anciso, J.; Ivanek, R. Risk factors for microbial contamination in fruits and vegetables at the preharvest level: A systematic review. J. Food Prot. 2012, 75, 2055-2081. [CrossRef] [PubMed]

13. Nirmal, N.P.; Benjakul, S.; Ahmad, M.; Arfat, Y.A.; Panichayupakaranant, P. Undesirable Enzymatic Browning in Crustaceans: Causative Effects and Its Inhibition by Phenolic Compounds. Crit. Rev. Food Sci. Nutr. 2015, 55, 1992-2003. [CrossRef] [PubMed]

14. Chudnova, O.A.; Oleinik, E.A.; Melnikov, P.A. Dairy products quality assurance at the consumer market in compliance with EEC requirements. IOP Conf. Ser. Earth Environ. Sci. 2020, 422, 012041. [CrossRef]

15. Bhat, R.; Jõudu, I. Chapter 2-Emerging issues and challenges in agri-food supply chain. In Sustainable Food Supply Chains; Accorsi, R., Manzini, R., Eds.; Academic Press: Cambridge, MA, USA, 2019; pp. $23-37$. ISBN 978-0-12-813411-5.

16. Dudin, M.N.; Frolova, E.E.; Gryzunova, N.V.; Shuvalova, E.B. The deming cycle (PDCA) concept as an efficient tool for continuous quality improvement in the agribusiness. Asian Soc. Sci. 2014, 11, $239-246$. [CrossRef]

17. He, Y.; Huang, H.; Li, D.; Shi, C.; Wu, S.J. Quality and Operations Management in Food Supply Chains: A Literature Review. J. Food Qual. 2018, 2018, 1-14. [CrossRef]

18. Basir, S.A.; Davies, J.; Douglas, J.; Douglas, A. The influence of academic culture on quality management system ISO 9001 maintenance within Malaysian universities. J. High. Educ. Policy Manag. 2017, 39, 320-340. [CrossRef]

19. Wognum, P.M.; Bremmers, H.; Trienekens, J.H.; van der Vorst, J.G.A.J.; Bloemhof, J.M. Systems for sustainability and transparency of food supply chains-Current status and challenges. Adv. Eng. Inform. 2011, 25, 65-76. [CrossRef]

20. MacCarthy, B.L.; Blome, C.; Olhager, J.; Srai, J.S.; Zhao, X. Supply chain evolution-Theory, concepts and science. Int. J. Oper. Prod. Manag. 2016, 36, 1696-1718. [CrossRef]

21. Al-Tabbaa, O.; Ankrah, S. Social capital to facilitate 'engineered' university-industry collaboration for technology transfer: A dynamic perspective. Technol. Forecast. Soc. Chang. 2016, 104, 1-15. [CrossRef] 